\title{
Po/etisk pedagogisk ledelse for kvalitet gjennom skriving mot immanente vurderingspraksiser og tvilens og kroppens vitenskap og metoder
}

\author{
Anne Reinertsen, \\ Dronning Mauds Minnes Høgskole for barnehagelærerutdanning, abr@dmmh.no \\ Nina Rossholt, \\ Høgskolen i Oslo og Akershus, Nina.Rossholt@hioa.no
}

\begin{abstract}
:
This article is about po/ethic pedagogical leadership and quality in a posthuman perspective. It is about embodied knowledge and knowing: Leadership between and other. We want to expand on conceptions of critique, increase the depth in - and strengthen our analytical gases. It implies a move from hermaneutic to immanent theories of assessment and leadership. It is a sciencing up and pedagogical diffraction; Natural-, human-, and social sciences and research are process-ontologically written together.
\end{abstract}

Key words: Leadership. Immanent assessment practices. Diffractive pedagogies. Affirmative po/ethics. Subjective professionalism. Ontological turn in research and development.

Ingress:

Artikkelen handler om po/etisk pedagogisk ledelse og kvalitet i et posthumant perspektiv. Den handler om kroppslig kunnskap og viten. Ledelse mellom og omvendt. Sentralt står et $\emptyset n s k e$ om å utvide vår forståelse av kritikk, øke dybden i-og styrking av våre analytiske blikk. Det innebærer en bevegelse fra hermeneutikk til immanente teorier for ledelse og kvalitetsvurdering. Det er en vitenskapeliggjøring og diffraksjon av pedagogikken hvor naturvitenskapelige, human, - og samfunnsvitenskapelige aspekter sidestilles i prosess ontologisk samtidighet.

Nøkkelord: Ledelse. Barnehage. Posthumanisme. Immanente vurderingspraksiser. Diffraktive pedagogikker. Prosess kvalitet. Po/etikk, Profesjonsut $ø v e r e$, Ontologisk vending i forskning og utvikling.

\section{Bevegelser i kvalitet}

I denne artikkelen tar vi leseren med inn i det posthumane landskapet, her med vekt på den franske filosofen Gilles Deleuze (1925-1995) og psykoanalytikeren Félix Guattari (1930-1992): Deleuze og Guattaris (1987) immanens filosofi, den organløse kroppen eller konsistensplanet. De la, sammen med bl.a. Michel Foucault (1926-1984) og Jacques Derrida (1930 -2004) grunnlaget for poststrukturell og posthuman filosofi og forskning med fokus på dekonstruksjon og en utvidet relasjonstenkning. Det inkluderer materialitet og også det som ikke er menneskelig eller det -mer- 
enn- menneskelige. Vi kaller det materielt-diskursive innganger til forskning og utvikling der vi er mer opptatt av hva ting gjør, skaper og produserer enn hva ting er og identitet, og videre er vi som forskere med i produksjonen og blir slik til (becoming). Vi beveger oss fra den språklige til den ontologiske og affektive vendingen i forskning og utvikling, hvor språket altså også er materielt og at våre virkeligheter skapes materielt diskursivt.

Ontologi handler om tingenes vesen og hvordan mennesker oppfatter og tenker. Hvordan vi tenker om tingenes vesen varierer mellom mennesker. Ontologi handler derfor ikke om rekkefølgen til ting eller inndeling og kategorisering, men om det som kommer fram gjennom praksis og i prosess.

Deleuze og Guattari (1987) etablerer et tenkende territorium i immanensplanet som en forutsetning for filosofisk tenkning. Det handler om her og nå handlinger som da skaper utgangspunkt for et tenkende territorium. Alt er alltid i bevegelse og i det jeg har tenkt en tanke om for eksempel ledelse er den tanken på vei et annet sted nettopp fordi mine tanker er flyktige. Spindler (2013) diskuterer i boken Deleuze, tänkande og blivande nettopp fenomenet tenkning: Bildet på, eller en oppfatning og figurasjon av tenkning handler for Deleuze om en uendelig bevegelse, og at det er det som konstituerer tenkning (bevegelse som selve tenkningen) (s. 40). Det å tenke, og tenkning som fenomen kobler Deleuze til immansfilosofi: Mulighetsrom som tenkende territorier eller; kritisk nytenking om egen praksis, om barnehagen og om oss selv (og ledelse) igjen og igjen. Tenkningens tilblivelser stiller altså spørsmål til hvordan vi tenker: Hvordan tenker jeg? Videre skaper Deleuze, slik vi skal se, også nye ord å tenke med. Det er ord som brukes på andre områder enn de er tenkt eller nye sammensetninger av ord. Og slik vi ser det, skapes da po/etiske mulighetsrom. Deleuze ord tvinger oss til å tenke (Spindler, 2013). Starten kan være et «tenkende territorium» og som mennesker er vi tenkende territorier (Deleuze, 2004. s. 44). Mennesker reterritorialiserer og deterritorialiserer igjen og igjen. Det betyr at alt er mulig og at alt kan komme til å få betydning hvis vi vil. Det gjelder oss som forfattere av denne teksten, og det gjelder utviklingsarbeidet i barnehagen. Det gjelder ledelse hvor man bygger inn po/etisk dynamikk fra start for kvalitet (Reinertsen, 2015a).

Affekt gir verdi til hvordan vi samtidig påvirker og blir påvirket i gjensidighetsprosesser. Her prosessuelle skriveprosesser. Massumi (2015) hevder at affekt handler om å åpne kroppen for ubestemmelighet og fokusere på det ekstra eller det noe som opererer i tillegg «under» bevisstheten. Han bygger videre på Spinozas betydning for det å betrakte det å «påvirke» og å bli "påvirket» som den samme kraften; "When you affect something, you are at the same time opening yourself up to being affected in turn, and in a slightly different way than you might have been the moment before" (Massumi, 2015, s. 4). Affekt blir slik en terskel opplevelse eller erfaring, en overgang som er mulig i det daglige og som kroppsliggjøres.

Når vi følger Deleuze og Guattari (1987), Massumi (2015) og Barad (2007, 2014), kan kanskje en i snever forstand, kroppslig årsak/virknings logikk slippe taket, og en mer sensitiv tilnærming i forhold mellom profesjonsut $\varnothing v e r e$, her deltakere i prosessuelle skriveprosesser, komme til syne, der det sansemessige løfter fram, bevegelser i kropper, lukter og lyder som slik får en eksplisitt verdi. Det gjelder samtidig i forhold mellom forskere og forskerdeltakere (Reinertsen, 2007/09, Rossholt, 2016). Kunnskap gjennom sansing, er en utforskende posisjon der tillitt blir gitt til det umiddelbare, det ustrukturerte og uformelle i det ordet eller det som sies ofte ikke favner det som sanses mellom mennesker i en profesjonell og ikke profesjonell kontekst. Vi må bruke ord når vi kommuniserer $\mathrm{i}$ hverdagen, men vi problematiserer i artikkelen hvordan ord brukes. Vi prøver ut et poetisk språk, et språk som følger bevegelsene og rytmen, til en ny toneart og nye tanker, en organisasjonslærings,og utviklingsmetodologi som rommer tvilens mellomrom.

Det innebærer å rekonseptualisere kvalitet, og alle andre konsepter, som alltid å være i bevegelse som tilblivende prosesser, eller som Manning og Massumi (2014, s.10) uttrykker det: thinking with movement. Tilblivende prosesser handler om eksperimentering med hvordan «ting/objekter» inkluderer figurasjoner og også mer enn mennesker (Jones, Rossholt, Anasatsiou, Holmes, 2016, s. 7; Reinertsen, 2016, s. 4.). Hvert ord blir, slik vi allerede har diskutert, en søken etter hvordan det (ordet) ser ut i praksis akkurat nå, eller det å kjenne igjen ledelse for kvalitet når du ser det. Det gjør 
på en måte ledelse til noe lite og stort samtidig, og den arenaen man bygger for å tenke nytt blir et sted hvor man dekonstruerer egne ord og praksiser for å fylle dem med ny mening igjen og igjen. $\mathrm{Vi}$ kan da skape nye ord eller sette ord sammen på nytt, jf. po/etikk, som igjen kan berøre på nye og andre måter enn tidligere. Sett i lys av barnehagen som samfunnsinstitusjon, og som første ledd $i$ et utdanningsløp (Stortingsmelding 19, 2016) argumenterer vi for et fokus på kvalitetsbegrepet i en her og nå kontekst, kvalitet som et sanselig fenomen.

\section{Po/etisk pedagogisk ledelse for kvalitet gjennom skriving}

Jeg er usikker på om det er veiledning eller ulike prosesser i ledelse som foregår. Veiledning er jo tradisjonelt sett et bilde på at man skal følge veisøker. Man kommer og skal være nær og sensitiv $i$ forhold til at veisøker skal bevege seg i sitt tempo med sin problemstilling. Veisøker initierer hva han/hun har lyst til å jobbe med. Men vi har jo på en måte snudd det opp ned og sagt at det er dette eller dette vi skal jobbe med: Hvor står du i det? Og hvordan tenker du at veien kan bli til videre for deg framover? Slik at vi har pålagt veiledning. Det er ikke frivillig og noe du initierer selv. Veiledningen er styrt (Intervju 10. 09. 15).

Denne historien tilhører en internveileder i en stor barnehage med elleve avdelinger i ulike bygninger. Hver avdeling har månedlige møter hvor det arbeides med et tema som er bestemt for et halvt år av gangen. Det være seg danning, læring, lek, bevegelse, språk, pedagogisk dokumentasjon, barns kunstuttrykk osv. Målet er en lærende organisasjon og skriving er valgt som både metode og kompetansestrategi. Alle ansatte skriver. Det kan være en kort eller lang historie eller kun en fragmentert setning eller to. På møtene er det det som er skrevet som diskuteres og kritisk reflekteres over, eller mer presist differensieres. Vi kan si at skriving er valgt som barnehagens sprednings, - og diffraksjonsapparat for å skape brytninger i og om egne praksiser. Begrepet praksisfortelling brukes imidlertid ikke da det har konnotasjoner til mer komplette tekster, hvor alle begreper er klart definert, og med en forventning om klart og godt strukturert innhold. Videre er tradisjonelt målet med å arbeide med praksisfortellinger det å reflektere over egne praksiser med det for фye å finne felles pedagogisk forståelse og ståsted.

Kun ved en slik svært begrenset beskrivelse og kontekst, ser vi at barnehagen det her er snakk om utfordrer eksisterende oppfatninger og praksiser. Barnehagen $\emptyset$ nsker forskjeller, utvidelser og spredning velkommen. Forståelsen av begreper åpnes opp og settes spørsmålstegn ved. Målet er fellesskap og ledelse for læring og kvalitet, ikke læring av noe bestemt og det samme for alle. Det innebærer blant annet et syn på ledelse bort fra ideer om individuelt agentskap og kontroll, til å ta i betraktning de materielt diskursive (makt)relasjoner som til enhver tid former dynamiske prosesser $\mathrm{i}$ organisasjoner. Slik re-tenking av ledelse er samtidig da, slik vi ser det, både betingelse for - og utløser av behov og mulighet for nye teoretiske og praktiske posthumane utforskninger. Det er i lys av slike utforskninger denne artikkelen kan leses. Den er delvis rotete. Den inneholder meta-metakommunikative aspekter. Noen formuleringer framstår som uferdige. Det er et poetisk grep for å åpne opp for det enda ikke tenkte/artikulerte.

Intervju med internveilederen i barnehagen utgjør det ene empiriske utgangspunktet for artikkelen. Det andre utgjøres av et nyblikk på et tidligere forskningsarbeid hvor ledelse kommer fram implisitt og uten å være del av en ledelsesteori. Det sanselige får slik status som kunnskap, ikke som føleri, men som det første mellom mennesker, noe før ordene kanskje. Ikke som noe enten eller, men som en dimensjon som alltid er der, men som ofte ikke blir ordsatt. Kanskje blir slik kunnskap mer lyttet til? Det kan også tenkes at det er forskeren som ikke lytter det det som ikke sies. Det er mye som skjer mellom mennesker som ikke sies.

Vi beveger oss derfor mellom ulike eksplisitte og implisitte lag av praksiser, teorier, policy dokumenter, samfunnsmandat, målsettinger om organisasjonsutvikling og læring, ferske intervjudata og feltnotater fra tidligere forskning. Fortid, nåtid og framtid skrives også her, og igjen, diffraktivt sammen i mellomrommene som oppstår. Perspektiver åpnes opp og utvides. Diskusjoner om 
kvalitet, samfunnsmandat, kunnskap og sanselighet kommer ultimativt sammen i, former for rettferdighet.

Diffraksjonsbegrepet er hentet fra fysikkens verden og refererer til bøyningsfenomener ved forplantning av for eksempel lyd eller lys bølger. Når bølger møter motstand spres de i ulike mønstre. Beslutningstaking eller her kritikk og kvalitetsvurdering bygges da inn som en kontinuerlig gjentakende eller iterativ prosess, og tar form som diffraksjon når nye handlingsmuligheter spres, og som refraksjon når bruddene mellom handling og ord skaper nye muligheter for handlinger i praksis (Barad, 2007, 2014). Det kan kanskje best beskrives som utvikling av en fagkompetanse som settes i bevegelse og fleksibelt tas i bruk. Fokus på refleksjon over et tema erstattes med fokus mot spredning eller altså diffraksjon: Det temaet man til enhver tid arbeider med- og hva det eventuelt innebærer, vil denne måten stadig utdypes, utvides og nyanseres i nye sammenhenger. Behovet for å rette fokus på prosesser for å skape felles forståelse og oppfatning av et begrep eller tema faller altså bort. Tvert imot blir det å holde begrepene åpne for eventuelt nytt innhold en ressurs og mulighet for læring.

Som veileder skaper jeg nok nye innganger som er ukjent for mange. Jeg utfordrer mer til kritisk refleksjon i forhold til det vi har gjort tidligere som var kun refleksjon. Jeg åpner opp for å tenke at hvis vi skal være noe annet enn det vi er i dag, hva kan vi gjøre da? Jeg har en struktur i veiledningen som gjør at alle er forpliktet til å involvere seg og bidra i refleksjon. Det er slik mer ledelse av kritiske refleksjonsprosesser. Jeg tenker på meg selv som leder i veiledning. Men det som kanskje er litt annerledes er at veien blir til sammen mens vi går. Jeg må tørre at framtida står åpen for oss (Intervju 10. 09. 15).

Skrivingen er autoetnografisk med klare autobiografiske innslag. Den danner grunnlag for overskridende prosesser som samtidig forankrer og forandrer (Reinertsen, 2015b). Det skriftlige språket blir slik en kraft for å oppdage sentrale perspektiver ved virkeligheten, og om seg selv (Richardson \& St.Pierre, 2005). Kvalitet sees på som en genererende kraft som kommer fram i skriving, uavhengig av de ulike komplekse uttrykkene det har, som tilblivelsesprosesser. På denne måten skriver personalet fram prosessuelle betingelser for kvalitet i barnehagen: De skriver for så $\mathrm{i}$ neste $\varnothing$ yeblikk å oppheve det til noe annet, en kontinuerlig prosess. Eller som veilederen også uttrykte: «Danning er nå et ord vi tar med oss og ser etter i praksis» (Intervju 10. 09. 15). Det er en inngang til pedagogikken som anerkjenner materialitet og dets betydning for vår tenkning og våre handlinger, eller som Barad (2007) uttrykker det: «When matter comes to matter». Her i en kontekst hvor skrivingen materialiserer seg kroppslig og synliggjør den sanselige verden i barnehagen.

Prosessuelle skriveprosesser er åpenbart ikke nødvendigvis lineære eller bygget opp gjennom kun kognitive kausale relasjoner og forhold, og kan dermed heller ikke ledes med utgangspunkt i at det er det de er. Ordene beveger seg i historiene personalet skriver ned, og de samme ordene får altså nytt innhold underveis og i bruk. Ordene står i spenning, i mellomrom og i samtidighet. De rører, berører og rører berører oss igjen og igjen, men ulikt. Eller sagt på en annen måte; de får ulik mening og innhold etter hvert som de brukes. Ser vi på intervjudataene vi presenterer underveis, ser vi for eksempel at: Veiledning blir ledelse blir strukturert og styrt, men åpent, individuelt og kollektivt internt og eksternt. Kritikk blir refleksjon blir kunnskaping. Praksis blir tenking blir profesjon blir språk. Kunnskaping blir skriving blir prosess blir ledelse blir veiledning.

Kanskje kan vi da snakke om ledelse mellom og at nye dimensjoner og muligheter bygges inn $\mathrm{i}$ ordene etter hvert som de brukes. Kanskje kan vi snakke om po/etisk ledelse eller at hvert ord vi bruker kan ses på som et dikt som gir og åpner poetiske muligheter, og slik vi ser det; bidrar til analytisk dybde og en etikk. En etikk med det for øye å komme nærmere det enkelte barn i forskjell. En etikk hvor endringskapasitet og transparens bygges inn langs et kontinuum av bevegelser som spenner fra det personlige til det politiske. Barnehagens og barndommens diskurser politiseres i et 
mikroperspektiv gjennom skriving og måten det skrives; som auto/etno/bio/grafiske dikt. Den enkelte profesjonsut $\varnothing v e r$ skriver frem seg selv og sitt oppdrag som ikke-reduserbare dynamiske aktiviteter som omgjøres til en kraft som blir gjensidig virksom i utvidede voksen-voksen og voksenbarn relasjoner. Det innebærer en bevegelse fra hermeneutikk til immanente teorier for ledelse og kvalitetsvurdering. Hermeneutikk som uttrykk for linearitet og kausalitet, mens immanens utrykker spredingspotensialitet og muligheter for utvidelser og endring gjennom brudd og forskjell. En annen måte å også karakterisere slike prosesser på er omvendt kunnskaping, hvor utgangspunktet er den kunnskapen som gjennom egen kraft og krefter skapes på stedet. Ledelse mellom blir også slik omvendt og situert. Slik vi ser det er dette i tråd med de politiske målsettingene vi har om å styrke barnehagebaserte utvikling- og læringsprosesser. -Å for å metakommunisere litt nå; her slår et policy dokument inn i vår framstilling, men på en annen måte. Vi skriver ikke for å følge noe opp, men for å re-tenke og situere dets innhold.

Ledelse handler, slik jeg ser det, om å skape en arena for å tenke nytt om egen praksis, om barnehagen og om oss selv. Vi er på veg mot et profesjonsspråk. Vi utfordrer oss på det både gjennom tekst og tale. Vi visste ikke at vi var i stand til å skape kunnskap selv. Vi trodde vi måtte ut å få tak i den kunnskapen. Nå ser vi at vi gjennom å skrive våre praksiser i større grad skaper kunnskap selv (Intervju 10. 09. 15).

I fortsettelsen ønsker vi å diskuterer po/etisk pedagogisk ledelse gjennom begrepene immanens, nomadologi og rhizom, for så å knytte diskusjon opp mot språk og forståelsen av dynamikken i språket. Vi er på vei mot et mindre språk for kvalitet. Med det mener vi at vi utforsker tvilens og kroppens logikker mer enn de lineare og nytte baserte logikker. Det neste punktet omhandler poetisering av praksis og metodiske utvidelsesmuligheter for å øke dybde og styrken i våre analytiske praksiser både som profesjonsut øvere og forskere. Det innebærer til syvende og sist en viteskapeliggjøring av selvet. Allerede Aristoteles argumenterte for at poesi er mer sant enn historien, og siden det har forfattere, forskere og skribenter brukt poesi for å beskrive livet slik vi erfarer og opplever det. Vi går fra normative til analytiske pedagogikker på grensen mellom human,samfunns,- og naturvitenskaplige tilnærminger.

\section{Mot immanente vurderingspraksiser; tvilens og kroppens metoder} I boka «Tusen Platåer» (Deleuze og Guattari, 1987) anvendes rhizomet (i motsetning til rot metaforen) som bilde eller metafor på hvor komplekse, diffraktive, sammensatte eller sammenflettede/-vevde immanens, plan, platåer eller territorier er. Videre anvendes nomadologi som betegnelse for de aktivitetene som kreves av oss, som vi ønsker, og som skal bevege oss mellom ulike platåer for ledelse for kvalitet eller stadige deterritorialiseringer og reterritorialiseringer. Som nomader beveger vi oss i stadige tilblivelsesprosesser i ord og materie, og platåene vi skaper igjen og igjen kan best kun ses på som midlertidige ansamlinger (assemblages). Kritikk eller våre vurderingspraksiser blir nettverk blir rhizom. Det vi har gjort, kan alltid gjøres om, de beslutningene vi har tatt kan tas igjen.

A rhizome ceaselessly establishes connections between semiotic chains, organizations of power, and circumstances relative to the arts, sciences, and social struggles. A semiotic chain is like a tuber agglomerating diverse acts, not only linguistic, but also perceptive, mimetic, gestural, and cognitive: there is no language in itself, nor are there any linguistic universals, only a throng of dialects, patois, slangs, and specialized languages (Deleuze and Guattari, 1987, s.7).

Denne affektive vendingen i forskning og utvikling gir, som nevnt, verdi til hvordan vi påvirker og blir påvirket. Det gjelder også forskeren og handler da igjen om utvidelser og å sette hele 
forskningsprosessen fra datainnsamling til resultat under erosjon (Gregg \& Seigworth, 2010). Det handler om kunnskap produsert gjennom sansing og sansing brukt for å skape kunnskap. Det er slik vi ser det helt i tråd med det vi her beskriver som prosessuelle skriveprosesser i barnehagen som lærende organisasjon. Det innebærer uansett ståsted som forsker eller profesjonsut $ø$ ver i en barnehage, stadige rekonseptualiseringer av kvalitet for ledelse med utgangspunkt i bevegelser og her og nå relaterte logikker, konkretisert gjennom prosessuelle hendelser (Dahlberg, 2016). Kunnskapene som produses er imidlertid ulike og vil igjen være gjenstand for diffraksjoner og i ulike sammenhenger. En prosessuell hendelseslikende tilnærming til kvalitet åpner nettopp opp for det uventede, det som overrasker, ikke-kunnskap, og det som setter forskjellighet i bevegelse (Dahlberg, 2016). Det er en til/blivelsesontologi der intensiteter og krefter åpner opp for bevegelse, igjen og igjen, her og nå. Ethvert hierarki og hierarkisk tenkning sprenges åpent. Og for å understreke: Det innebærer også å rive ned hierarkiene som setter synet framfor de andre sansene; berøring, lukt, smak, lyd. Altså ikke å gi privilegium til det å se framfor andre sanser. Her blir tvil en form for immanent mangfoldighet (Spindler, 2013).

Manning and Massumi (2014) hevder at det å være oppmerksom på det ekstra og det som også er mer enn menneskelig står nært det å erfare det de benevner som:

"fullness of a dance of attention" (s. 4): "A dance of attention is the holding pattern of an immersive, almost unidentifiable set of forces that modulate the event in the immediateness of its coming to expression. Attention not to, but with and toward, in and around" (s. 4).

Det er bevegelser og dette annet som vi ikke vet hva er. De legger også til at typisk og vanligvis er:

"the field of experience is pre-perfused with for-ness. It is already tending toward expression in use-value - rather than entertaining expressibility on its own account" (ibid, s. 8).

\section{Et mindre språk for kvalitet}

Å skrive fram og å forske på det vi ikke vet krever nye ord. Det krever «strekkeøvelser» (Janesick, 2016). Vi må ut av hovedspråket og inn i et som er mindre. Det er et mindre kvalitetsspråk eller «et mindre språk» om kvalitet: Et språk "uten store ord" (Reinertsen, 2015a, 2016). Begrepet «et mindre språk» henger sammen med Deleuze og Guattaris (1987) arbeid med en «mindre litteratur». De trekker fram James Joyce og Samuel Beckett som forskjellige, men potente eksempler: Joyce som en heller hyperbolsk skribent, mens Beckett som skaper av en tørr og «villet magerhet» (s.19), men som likevel produserer affekter gjennom å forstyrre rom, tid og lyd. En mindre litteratur har tre egenskaper eller karakteristika: Språket som blir brukt er påvirket av deterritorialiseringer og dermed strippet fra syntaks og har slik mistet all symbolisme og betydning. Ord og betydning er altså fradelt og kan samtidig fylles med ny mening. Videre, er alt språk politisk og vi som individer blir knyttet til en politisk umiddelbarhet. Sist, men ikke minst; alt har kollektiv verdi fra eller med samlingene som settes i spill "assemblages coming into play" (s. 27). Aktualisert gjennom elementers relasjonelle og komplekse vitalitet som egentlig markerer selve den posthumane tenkning. En mindre litteratur som har blitt skapt gjennom et majoritetsspråk av en minoritet tilbyr muligheter for å artikulere nye politiske subjektiviteter:

"Minor literatures that have been created in major languages by minorities offer great possibilities for the articulation of new political subjectivities" (Allan, 2013, s.39).

Slike mindre litteraturer og da mindre språk, kan brukes til å navngi $X$ og mobilisere politisk, men samtidig arbeider de for å underminere det suverene subjekt. l et mindre språk handler det her da om blandingsspråk eller å bli tospråklig gjennom skriving for å skape metodiske utvidelsesmuligheter

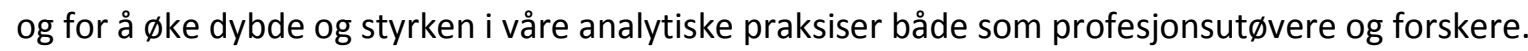


Deleuze kaller ordet for "aion" (Deleuze, 1990, s.1). Det er alltid bortenfor tegnenes regimer og tillater oss derfor å tenke forskjellig om ethvert begrep eller ord, og det Deleuze og Guattari gjentakende kaller en noology. Kjennetegnet til Deleuze og Guattari er da også at de konstant lager nye ord, bruker ord i andre sammenhenger enn de tradisjonelt brukes i og oppfordrer oss alle til å gjøre det samme. Hvert ord blir slik en hendelse (event) og bevegelse som alltid starter med og analysere:'the states of things, in such a way that non-pre-existent concepts can be extracted from them" (Deleuze \& Parnet, 2002, s. vii). Det innebærer konstant nytenking av sammenbindinger mellom ord, kropper,selvet og andre: tekstlag på tekstlag. Uryddig, ubestemmelig, poetisk, hyperbolske og gjentakende eller det å konstant "sette - sammen - fra" (putting - together - apart ) (Barad, 2014). Hvert ord blir et dikt. Ord blir poesi. Kritikk blir immanent, blir nettverk, blir rhizom. Det vi har gjort, kan alltid gjøres om, de beslutningene vi har tatt kan tas igjen. Ledelse blir kvalitet blir kroppslig kunnskap og viten. Barnehagen blir et sted for poesi. Den blir kreativ og immanent... liv...

Immanent betyr «iboende», eller noe som er i tingen selv som en potensialitet. Alt er alltid og alt er mulig. Absolutt immanens er slik i seg selv. Det er ikke i noe eller i forhold til noe. Det avhenger ikke av et objekt eller et tilhørende subjekt. Substans blir slik kun eventuelle modaliteter i immanensen. Immans er livet og ikke noe annet. Det er ikke immanens i forhold til liv, men det immanente, som er intet, som er selv et liv. Alt er uten. Det som skjer og enhver aktivitet skjer da ikke under henvisning til et værende, men som uopphørlig framstilt i et liv. Et liv av potensialitet i hvert $\varnothing$ yeblikk, som er liv. Slike $\varnothing$ yeblikk er en haeccicitet. Haptiske kvaliteter er læren om berøring, hvordan vi bruker hender og fingre og føtter for å utforske omgivelsene. Filosofen og kunstneren Francis Bacon arbeider beskriver begivenheter der et haptisk syn dominerer over et optisk syn (Carlsen, Nielsen og Rasmussen, 2001). Et liv i immanens er hinsides godt og ondt. Det er et liv med kunnskap.

Derfor inneholder et liv, her lest som ledelse kun virtualiteter. Livet og ledelse er skapt av virtualiteter, begivenheter og singulariteter. Det betyr ikke mangel på realitet, men at noe tar del i en aktualiserings prosess. Den immanente begivenhet er aktualisert $\mathrm{i}$ tingenes tilstand og av det levende som får det/noe til å skje. Immanensplanet er også virtuelt så lenge begivenhetene er virtualiteter, eller sagt på en annen måte alltid tilblivende, alltid på vei til noe annet, åpent. Det eneste som da finnes er forholdet mellom bevegelse og hvile i motsetning til fiksering, essens og enhet (Spindler, 2013).

Det mangfoldige og komplekse trer slik i større grad fram i det som hele tiden viser seg for meg og deg. Det er som når man leser noter og spiller piano, så må man være like opptatt av, og oppmerksom på mellomrommene mellom som av selve notene. Det skaper følelser og legger til sjel i spillet. Det skaper unike klanger i rommet. Først da kan vi si at musikeren skaper, skulpterer eller dikter ett/sitt verk. Musikkstykket stiger fram i 3D format og vi andre/publikum kan se, høre og bli med (Reinertsen, 2015a). Slik kan vi også tenke om ledere og po/etisk pedagogisk ledelse. Ledelse i 3D format her og nå; hver gang vi spiller. Vi spiller og dikter forskjellig hver gang og igjen og igjen, og kanskje er det en oppmerksomhetsdans vi leder, spiller, danser, gjør.

\section{Å skrive kropper og tvil igjen og igjen}

I likhet med personalet kan også forskeren prøve ut et po/etisk, sansemessig språk.

"Ha det bra vennen min». Nasji stirrer på meg, hennes store brune Øyne er fylt med tårer, flere tårer kommer da hun sier: "Pappa kommer snart, pappa kommer snart». Lise, assistenten, løfter Nasji opp, og kroppene deres er helt inntil hverandre nå. Lise sier: "Jeg kjenner hjertet ditt slår saktere nå, Nasji». Lise står en stund med Nasji i armene sine. Hun vugger henne sakte, så går hun inn i spiserommet og setter Nasji ned på en stol. Nasji har sluttet å gråte. Hun ser seg rundt og blir sittende stille i et par minutter. Så stiller hun seg $i$ døra til lekerommet. Døra er åpen, og Nasji holder i dørhåndtaket. Nasji tar et skritt inn, står 
og ser på de andre barna, og tar et skritt til. Døren blir lukket bak henne. Nasji begynner og gråte. Døren blir lukket opp, og Nasji kan stå i døråpningen mellom de to rommene igjen. (Feltnotater, november, 12, 2010)

Gråten lever i barnehagen, og den møtes hele tiden av personalet, men det er ikke alltid personalet ordsetter gråten po/etisk, mangfoldig. Det er ikke alltid nok kropper, hender, øyne tid og hvile i $\varnothing$ yeblikket til å ta det som skjer inn på måter som føles etisk. Kropper er hele tiden tett på hverandre i barnehagen og kunnskapen om nettopp det, kan formidles på mange måter. Når vi setter tvilens og kroppens vitenskap og metoder fram som det første, som pedagogisk kvalitet, som ledelse, vil kanskje en mer likeverdig kunnskapsposisjon tre fram, personalet skal ikke lære av hverandre, eller av eksperter, men lære om seg selv, og hvordan bevegelser i kropper og materialer virker sammen. En rhizomatisk reise mot immanente vurderingspraksisene, der skjemaene er færre og det sansemessige trer frem. Det kan åpne opp for det mangfoldige, immanent mangfoldighet (Spindler, 2013).

Hvorfor ser forskeren det hun «ser» og sanser, og hvorfor «ser» personalet det de «ser» og sanser? । artikkelen Food as touch/touching the food: The body in-place and out-of-place in preschool (Rossholt, 2012) tematiserer forskeren hvorfor hun "ser"det hun "ser". Hennes liv, hennes oppvekst gjør at forskeren rettet forskningsfokuset i barnehagen mot måltidet. Det handler ikke om hennes selv, men mer hvordan gjøre det kjente, ukjent. Her ble begrepet berøring/å bli berørt, en haptisk inngang, der hender og kropper tett inn til hverandre gir rom for andre relasjoner enn blikk som skuer begivenheter fra en avstand (Derrida, 2005). Poesi kan assistere i den prosessen. En poetisk inngang kan styrke den analytiske kraft i alle deler av et forskningsprosjektet, og i vurderingene av egen praksis i barnehagen. Vi kan alle utvide våre territorier Deleuze og Guattari (2005), og vi gjør det hele tiden, men hvordan ordsetter vi det? Har vi et minoritetsspråk som favner livets kompleksitet, det sanselige, kroppslige, eller blir det slukt opp av majoritetsspråket?

Og det som er spennende og det jeg knytter til læring og at vi er så forskjellige. Og å løfte det inn $i$ et fellesskap og drøfter det, skaper brudd. Det tenker jeg skrivingen gjør i større grad, for når vi sitter sammen så mange så er det så lett at vi snakker og snakker og så bare flyter det rundt oss. Vi sitter $i$ et akvarium på en måte (Intervju 10.09. 15).

Et musikalsk språk trer igjen inn, følger vi naturen som musikk (Deleuze og Guattari s.402, 2007) et territorium låner fra et annet territorium, det er produkt av miljøer og rytmer. Rytmer brytes hele tiden i barnehagen, toner kommer i utakt, istedenfor å følge tonene og rytmene, minorspråket, trår majoritesspråket inn, det ryddes i symbolsk og konkret forstand.

Det er det virtuelle som her da fører oss videre mot det vi kan kalle poetiserende praksiser og etikk. Det innebærer å gjenerobre sporene av tilblivelsens begivenheter uten å sette det inn i en bestemt logikk eller narrative aspekter. Det er å utforske hvordan et poetisk øyeblikk hvor følelser, betydninger og mening er satt fri og hvor sansemessige tilblivelser fortsetter å virke. Diktet har slik sett evne til å transformere en hendelse inn i en annen hendelse og vi kan snakke om navigering $\mathrm{i}$ livet og po/etisk ledelse for kvalitet eller rett og slett innovasjon. Nytenking i ikke planlagte øyeblikk underveis i det daglige arbeidet. Valg av ekspertise i kontekst. Å være trygg på å lede i kompleksitet, en rhizomatisk inngang.

I barnehagen skriver de fram seg selv og det virker:

"Det vi oppdaget etter hvert var at vi skrev og lot oss berøre av det vi hadde skrevet. Vi kjente at vi hadde så sterke følelser knyttet til de opplevelsene vi hadde i praksis. Vi hadde så sterke følelser rundt det. Både i situasjonene når noe skjedde, men også når vi satt og snakket om dem. Vi felte tårer. 
Hvorfor ble vi så opprørt? Hvorfor ble vi så begeistret? Uten at vi fant noe svar på det, men vi satt og undret oss over hva er det som skjer med oss nå? Hva er det som foregår i dette rommet nå, mellom oss i deg i meg? Men det ble hengende i lufta og vi gikk ikke inn i det, men vi fortsatte å skrive fortellinger. Men det vi oppdaget etter hvert var at skrivingen åpnet blikkene våre. Vi oppdaget at barnehagen er et annet sted enn det vi trodde det var. Nesten som om vi strakk rammene for den virkeligheten vi var i. At det ble større for oss enn det det var tidligere. Vi ble del i noe større enn oss selv (Intervju 10. 09. 15).

Og for endelig å teoretisere auto-etnografisk skriving med autobiografiske trekk ytterligere: Norman Denzin definerer autobiografi på følgende måte: «A person's life written by oneself, inscribing and creating life» (1989, s. 10). En autobiografi kan skrives i førsteperson, og en biografisk metode kan potensielt da fange det dype indre livet til en person. Et liv er videre, et uferdig prosjekt eller mange prosjekter: «Every life is a moral, political, medical, technical, and economic production» (ibid. s. 29). Auto-etnografi er tradisjonelt definert som en form for selvrefleksjon og en skriving som utforsker skribentens egne erfaringer og binder dette til en videre kulturell, politisk og sosial sammenheng. Auto-etnografisk skriving er en dynamisk og kreativ prosess hvor man skriver for å oppdage; for å lære noe man ikke visste før man skrev det.

Denzin skiller videre mellom flere former for selvet: det fenomenologiske selvet, det språklige selvet, det materielle selvet som råvare, selvet som ideologisk subjekt og det begjærende selvet, som aldri blir helt fylt (ibid, s. 31). De ulike former for selv vil være tilstede på komplekse vis i alle personlige dokumenter og tekster. Subjektet skapes i relasjon til andre mennesker og ting, og handler derfor alltid samtidig om både seg selv, andre og annet, og slik muliggjøres det å bevege seg og navigere i ukjente rom (Chang, 2008; Ellis, 2004; Ellis, Adams \& Bochner, 2010). Og det det også gjør, når vi ser dybden og kompleksiteten i prosessene, er nettopp å bygge inn ydmykhet i de samme prosessene. Kun gjennom seg selv kan man da snakke om andre... kanskje. Derrida (1982) sier at «the perhaps» er den mest rettferdige kategorien å bruke i framtida. Steinsholt (2005) kaller det «det kanskjes pedagogikk». Vi kaller det, eksperimentert med her, tvilens og kroppens vitenskap og metoder. Ordenes strukturelle og normative føringer svekkes. Vitenskapeligheten og analytisk dybde styrkes og utdypes. Og for å sitere Knut Hamsun som argumenterte for en diktning med vekt på det uforutsigbare og irrasjonelle, de «sælsomme Nervevirksomheder, Blodets Hvisken, Benpibernes Bøn, hele det ubevidste Sjæleliv» ${ }^{1}$

For oss er skriving både teori, metode og praksis. For oss handler det om å bryte med det som er så kjent for oss. Det er for å bryte med det som vi flyter i med lover, rammer og ressurser. Men skriving blir et stopp punkt for oss der vi rett og slett tvinger oss selv til å sette oss ned og være kritiske. I stedet for å flyte med i strømmen, så lager vi oss slike stoppunkter: "Hei, det her må vi snakke om. Er dette greit? Kan vi nok om dette? Du forstår det slik, jeg forstår det på en annen måte.» (Intervju 10.09.15).

\section{Fra normativitet til forsterket po/etisk analyse}

Poesi kan styrke den analytiske kraft i alle deler av et prosessuelt prosjekt. Vi kaller det en vitenskapspoetikk som redskap for å styrke analytisk dybde: Ledelsespoetikk for kvalitet. Poesi kan fange det mirakuløse, det monstrøse, det overraskende eller kraften i et hverdags $\varnothing$ yeblikk. Poesi tenner gnister og bidrar til økt oppmerksomhet og kreativitet, bevissthet og selv-kunnskap: Jeg øker mine kunnskaper og blir bedre og bedre til å artikulere dem. Poesi åpner opp selve handlingen for

\footnotetext{
${ }^{1}$ https://no.wikipedia.org/wiki/Knut Hamsun
} 
nye og flere blikk på sosiale realiteter. Du blir aktiv meningsskaper i meningsskapende prosesser. Poesi har mange former og formater. Poeten representerer livet poetisk. Ingen forsker, veileder, leder eller poet gjør det samme som en annen. Ingen sier det samme som en annen. Derfor er det en generativ kvalitet ved poesien som utvider våre kunnskaps baser og våre forståelser av verden.

Poesi kan vi finne i tekstene vi skriver. Poesi kan vi bruke for å øke våre repertoarer av teknikker og metoder i vår streben etter våre egne. Når vi skriver og leser dikt i en gruppe eller en barnehage, skaper vi duetter mellom forsker og utforsket, eller hvilken som helst gruppe, og er vi på veg til å skape relasjoner, sammenbindinger; og fellesskap muliggjøres. Poesi tillater deltakelse i ideer, $\emptyset$ yeblikk av og tanker om såkalte verdier. Poesi inviterer til engasjement og aktivisme. Det utfordrer tradisjonelle måter å tenke på og er i stand til å vippe oss over i nye retninger slik enhver kunstform kan. Gjennom få ord, uten store ord kan poesi maksimere mening, skape ny poesi og kutte ut det overflødige og st $\varnothing$ yende. Poesi inspirerer til respekt og oppmerksomhet overfor andres historier. Poesi er en måte å bemyndige på.

Vi åpner opp for en sansemessig tilnærming til kunnskap, der den fysiske/materielle dimensjonen av livet løftes fram. Det sansemessige er nettopp livet selv, i en profesjonskontekst, er det nettopp gjennom det vi gjør at det nye trer fram. Således bryter vi diskursen om vante spor og praksiser som repeteres, når bevegelser i kropper og materialer står i sentrum. Videre konkretiserer vi hvordan både personalet, barna og forskeren kan aktivt bevege seg og analysere sine praksiser i et minoritetsspråk, en sanselig logikk.

Hvordan snakker vi om vår egen praksis og hvordan ordsetter vi det immanente, levd liv? Hvordan lytter vi til bråk, stillhet, gråt og latter, eller kan vi ikke skille det av? Istedenfor å snakke/skrive om det som allerede er definert kan en immanent inngang åpne opp for de kvalitative sanselige verdiene. Vi er i det allerede, men en barnehagehverdag kan være innskrevet i en kategoriserende logikk, da det er rutiner og programmer som skal følges

(Jones, Rossholt, Anastasiou \& Holmes, (2016); Rossholt, 2010). Hvor skal vi gjøre av alt alvoret, gleden, impulsiviteten? Det er der allerede, rett foran øynene våre. En poetisk og kreativ inngang er å følge barns og voksnes bevegelser. Ordene kommer fra kroppen, samtidig er ord tett sammenflettet med tempo i kropper. Lyder og stillhet, alt det som er mellom og uklart og mulig. Et poetisk språk kan være et utprøvende språk, et språk som tviler, prøver og prøver igjen. Det settes ikke punktum. Det er mange måter å skrive om livet i barnehagen på, her prøver vi ut en affektiv tilnærming, der kropper, ord og materialitet får en kunnskapsposisjon. Og ordene som toner og tempo beveger seg i barnehagen, beveger ordene seg her: Ledelse for kvalitet blir po/etikk blir politikk og/i skriving.

\section{Litteraturliste.}

Allan, J. (2013). Staged Interventions: Deleuze, Arts and Education in Deleuze and Education, I: Semetsky, I. \& Masny, D. (Eds.). Edinburgh: University Press Ltd, Edinburgh.

Barad, K. (2007). Meeting the universe halfway: quantum physics and the entanglement of matter and meaning. Durham: Duke University Press. http://dx.doi.org/10.1215/9780822388128

Barad, K. (2014). Diffracting Diffraction: Cutting Together-Apart. Parallax, 20(3), 168-187. http://dx.doi.org/10.1080/13534645.2014.927623

Chang, H. (2008). Autoethnography as method. Walnut Creek, CA: Left Coast Press.

Dahlberg, G. (2016). An ethico-aesthetic paradigm as an alternative discourse to the quality assurance discourse. Contemporary Issues in Early Childhood, 17(1), 124-133. http://dx.doi.org/10.1177/1463949115627910

Deleuze, G. \& Guattari, F. (1987). A thousand plateaus: Capitalism and schizophrenia. London: Athlone Press.

Deleuze, G. \& Parnet, C. (2002) Dialogues. New York: Colombia University Press

Deleuze, G. (1990) The Logic of Sense. (Trans. M. Lester, C. Stivale, \& C.V. Boundas (Ed.). New York: Columbia University Press. 
Deleuze, G. (2005) Ethology: Spinoza and us, I: M. Fraser \& M. Greco (eds), The Body, A Reader. (pp. 58-61). London: Routledge.

Deleuze, G. (2004). Foucault. Paris: Minuit.

Denzin, N. (1989). Interpretive biography. Qualitative research methods Vol 17, Sage University paper Derrida J. (1982). Margins of Philosophy. Chicago, IL University of Chicago Press.

Derrida, J. (2005). On Touching, Jean-Luc Nancy, Stanford, CA, Stanford University Press.

Ellis, C. (2004). The ethnographic I: A methodological novel about autoethnography. Walnut Creek, CA: AltaMira Press.

Ellis, C., Adams, T. E., \& Bochner, A. P. (2010). Autoethnography: An Overview [40 paragraphs]. Forum Qualitative Sozialforschung / Forum: Qualitative Social Research, 12(1), Art. 10, http://nbn-resolving.de/urn:nbn:de:0114-fas1101108.

Gregg, M. \& Seigworth, J..(2010). An Inventory of Shimmers. In The Affect Reader. Melissa Gregg \& Gregory J. Seigworth (Ed). (s.1-25). Duke University Press

Janesick, V. (2016). Poetic Inquiry: Using found poetry and identity poetry to transform qualitative data. In Becoming Earth; a new materialism turn in educational discourses collapsing nature culture divides or greenish post-anthroposcene humanities. Anne B. Reinertsen (Ed.) (31-40). Sense Publishers. The Netherlands. http://dx.doi.org/10.1007/978-94-6300-429-9_4

Jones, L., Rossholt, N., Anastasiou, T., \& Holmes, R. (2016). Masticating 'quality' and spitting the bits out. Contemporary Issues in Early Childhood, 17(1), 26-38. http://dx.doi.org/10.1177/1463949115627897

Manning, E. \& Massumi, B. (2014). Thought in the Act: Passages in the Ecology of Experience. Minneapolis: University of Minnesota Press. http://dx.doi.org/10.5749/minnesota/9780816679669.001.0001

Massumi, B. (2015). Politics of Affect. Polity Press, Cambridge.

Reinertsen, A.B. (2007/09). SPUNK - A Love story. Teacher community not; Writing towards a deauthorized and double(d) perspective of research and reform in schools. Doctoral thesis, NTNU. 2007. VDM Verlag 2009.

Reinertsen, A.B. (2015a). Uten store ord - Autoetnografisk etnometodologisk 3D skriving. I Metodefestival og øyeblikksrealisme. Otterstad, A.M. og Reinertsen, A.B. (red) (266- 295). Fagbokforlaget: Bergen.

Reinertsen, A.B. (2015b). A minor research and educational language: Beyond critique and the imperceptible beingness of engagement; creating spaces for collective subjectivity intensities, for change, and for social justice. Qualitative Inquiry; Vol. 21(7), 623-627 http://dx.doi.org/10.1177/1077800414555074

Reinertsen, A.B. (2016). A Phaedrus Baroque Art of Maintenance or Constant Fabulating Qualia Becoming Quality. Contemporary Issues in Early Childhood. Special Issue: Re-imagining quality in early childhood. Vol 17(1), 112-123 http://dx.doi.org/10.1177/1463949115627909

Richardson, L. \& St. Pierre, E. A. (2005). Writing: A Method of Inquiry. In Denzin, N. K. and Lincoln, Y.S. Handbook of Qualitative Research. Third Edition. Pp. 959-978. Thousand Oaks. Sage. California.

Rossholt, N. (2010) Gråtens mange ansikter: toner og tempo i barnehagen. Nordisk Pedagogisk Tidsskrift. 30(1), 63-76.

Rossholt, N. (2012) Food as Touch/Touching the Food: The body in-place and out-of-place Educational Philosophy, 44(3), 323-334.

Rossholt, N. (in progress). Thinking through movements: working with/in affect within the context of Norwegian early years education. Educational Philosophy and Theory.

Spindler, F. (2013) Deleuze, tänkande och blivande. Glänta produktion.

Steinsholt, K. (2005). Det Kanskjes Pedagogikk. In "Fra Moderne til Postmoderne Pedagogikk". Kompendium utgitt av Pedagogisk Institutt. University Of Trondheim; NTNU. Norway. Trondheim.

Norges offentlige utredninger (2016).19: Tid for lek og læring; bedre innhold i barnehagen. 